\title{
The expression and function of toll-like receptors (TLRs) in ovarian cancer cell lines
}

\author{
Shin-Wha Lee ${ }^{1 *}$, In-Kyung Lee², Sumin Kim², Sang-Eun Lee², Ha-Young Lee², Dong-Woo Kang ${ }^{2}$, Yong-Man Kim¹ \\ From 30th Annual Meeting and Associated Programs of the Society for Immunotherapy of Cancer (SITC 2015) \\ National Harbor, MD, USA. 4-8 November 2015
}

\section{Objective}

This study is to investigate which Toll Like Receptors (TLRs) are expressed on human ovarian cancer cell lines and to evaluate the effect of TLR expression on the growth of ovarian cancer cells.

\section{Methods}

Four human ovarian epithelial carcinoma cell lines SKOV3 (clear), OVCAR3 (serous papillary), SNU8 (serous papillary) and SNU251 (endometrioid) were used for the experiments. To find whether the expression of TLRs is functional on human ovarian cancer cell lines, cytokines (IL-6, IL-10, TNF- $\alpha$, IL-12, and IFN- $\gamma$ ) were investigated. For statistical analysis, one-way ANOVA with Tukey's multiple comparison post-test was carried out.

\section{Results}

In SKOV3 cell line, TLR 1-7 were expressed and among them, TLR-2, -3 and -5 have strong intensity; however, TLR 9 was absent and TLR 8 was weak. In OVCAR3 cell line, TLR 3 and TLR 5 were much more intense, and TLR-1, $-2,-4,-7$ and -8 were weak, while TLR 6 and TLR 9 were absent. Unlike other cell lines, SNU8 has strong intensity through TLR 1-9 although TLR9 was a little weaker than the others. In SNU251 cell line, TLR 15 and TLR 7-8 were expressed and TLR 6 and TLR 9 were absent or weak. The exposure of cells to ligands for TLR 1-9 showed significant upregulation of IL-6, especially in TLR 5. IL-10 after stimulating TLR 5 was significantly increased in SKOV3 and OVCAR3. Another proinflammatory cytokine TNF- $\alpha$ was assessed, and the result that only TLR 5 in OVCAR3 has a significant induction. IL-12p70 on TLR 9 was induced in the four cell lines but the result didn't show any significance and

${ }^{1}$ ASAN Medical Center, Seoul, Republic of Korea

Full list of author information is available at the end of the article
IFN- $\gamma$ was induced insignificantly in SKOV3 and OVCAR3 for TLR 9 only.

\section{Conclusion}

The expression and biologic function of TLRs are different in each ovarian cancer cell line. In order to target TLRs for the management of ovarian cancer, further studies are needed on the effects of TLRs in tumor development.

\section{Authors' details}

${ }^{1}$ ASAN Medical Center, Seoul, Republic of Korea. ${ }^{2}$ ASAN Institute for Life

Sciences, Seoul, Republic of Korea.

Published: 4 November 2015

doi:10.1186/2051-1426-3-S2-P76

Cite this article as: Lee et al:: The expression and function of toll-like receptors (TLRs) in ovarian cancer cell lines. Journal for ImmunoTherapy of Cancer 2015 3(Suppl 2):P76.
Submit your next manuscript to BioMed Central and take full advantage of:

- Convenient online submission

- Thorough peer review

- No space constraints or color figure charges

- Immediate publication on acceptance

- Inclusion in PubMed, CAS, Scopus and Google Scholar

- Research which is freely available for redistribution
() Biomed Central 